\title{
Evaluation of insulin antibodies and placental transfer of insulin aspart in pregnant women with type 1 diabetes mellitus
}

\author{
D. R. McCance • P. Damm • E. R. Mathiesen • M. Hod • \\ R. Kaaja • F. Dunne • L. E. Jensen • H. Mersebach
}

Received: 16 June 2008 / Accepted: 11 July 2008 / Published online: 23 August 2008

(C) Springer-Verlag 2008

Keywords Human insulin · Insulin antibody · Insulin aspart . Pregnancy Type 1 diabetes

\section{Abbreviations \\ HI human insulin \\ IAsp insulin aspart}

To the Editor: The relevance of insulin antibodies to neonatal outcome in pregnant women with diabetes remains unclear [1-3]. In one study of 138 pregnant women with type 1 diabetes, insulin antibodies were detected in the cord blood of $95 \%$ of the offspring at birth [3]. However, there was no evidence that insulin antibodies caused the transfer of insulin across the placental barrier or influenced birthweight.

To date, no study has investigated insulin antibody levels in pregnant women with type 1 diabetes treated with an

D. R. McCance $(\triangle)$

Regional Centre for Endocrinology and Diabetes,

Royal Victoria Hospital,

Belfast BT12 6BA, UK

e-mail: david.mccance@belfasttrust.hscni.net

\section{P. Damm}

Department of Obstetrics, Rigshospitalet, University Hospital of Copenhagen,

Copenhagen, Denmark

\section{E. R. Mathiesen}

Department of Endocrinology, Rigshospitalet,

Copenhagen, Denmark insulin analogue. In a recent randomised controlled trial we showed that prandial insulin aspart (IAsp), a rapid-acting insulin analogue, was as effective and well tolerated as soluble human insulin (HI) in pregnant women with type 1 diabetes $[4,5]$. The aim of the present study was to assess maternal and cord blood insulin antibody levels in a subset of 97 women who participated in the trial $[4,5]$. The evaluation was described in a post-initiation protocol amendment.

\section{Methods}

The study was performed in accordance with the Declaration of Helsinki and was approved by respective ethics committees and health authorities according to local regulations. Written informed consent was obtained from

M. Hod

Perinatal Division, Helen Schneider Hospital for Women,

Rabin Medical Center, Sackler Faculty of Medicine,

Tel Aviv University,

Petah-Tiqva, Israel

\section{R. Kaaja}

Department of Obstetrics and Gynecology,

Helsinki University Central Hospital,

Helsinki, Finland

F. Dunne

Medicine and Health Sciences,

Galway, Ireland

L. E. Jensen $\cdot$ H. Mersebach

Global Development, Novo Nordisk,

Bagsvaerd, Denmark 
Table 1 Median levels of maternal blood serum insulin antibodies at baseline and gestational week 36

\begin{tabular}{|c|c|c|c|c|c|c|c|}
\hline \multirow[t]{3}{*}{ Treatment } & \multirow[t]{3}{*}{ Antibody } & \multicolumn{6}{|c|}{ Maternal blood insulin antibody levels } \\
\hline & & \multicolumn{2}{|c|}{ Baseline } & \multicolumn{2}{|c|}{ Gestational week 36} & \multicolumn{2}{|c|}{ Change $^{\mathrm{a}}$} \\
\hline & & $n$ & Median (\%), range & $n$ & Median $(\%)$, range & $n$ & Median $(\%)$, range \\
\hline \multirow[t]{3}{*}{$\mathrm{IAsp}+\mathrm{NPH}$} & IAsp-specific & 34 & $0.3(-0.3-60.5)$ & 46 & $0.2(-0.3-45.0)$ & 30 & $-0.1(-15.5-0.3)$ \\
\hline & HI-specific & 34 & $-0.1(-1.2-5.6)$ & 46 & $-0.1(-0.8-5.9)$ & 30 & $0.0(-0.8-0.4)$ \\
\hline & Cross-reacting & 34 & $6.9(0.0-60.3)$ & 46 & $3.7(0.2-60.7)$ & 30 & $-2.2(-25.3-12.6)$ \\
\hline \multirow[t]{3}{*}{$\mathrm{HI}+\mathrm{NPH}$} & IAsp-specific & 33 & $0.3(-0.4-5.8)$ & 37 & $0.3(-0.3-33.3)$ & 23 & $-0.1(-2.1-2.9)$ \\
\hline & HI-specific & 33 & $-0.1(-0.5-12.6)$ & 37 & $0.0(-0.5-13.5)$ & 23 & $0.0(-2.8-1.0)$ \\
\hline & Cross-reacting & 33 & $8.6(-0.8-60.1)$ & 37 & $4.1(0.3-52.3)$ & 23 & $-2.7(-24.9-11.4)$ \\
\hline
\end{tabular}

${ }^{\text {a }}$ From baseline to gestational week 36

$\mathrm{NPH}$, neutral protamine Hagedorn

participants before study entry. Sampling of maternal blood was performed at baseline and at gestational week 36 for the determination of maternal insulin antibodies (HIspecific, IAsp-specific and cross-reacting). Immediately after delivery, umbilical cord blood samples were obtained and analysed for specific and cross-reacting insulin antibodies $(n=65)$ and serum insulin (IAsp and HI) $(n=30)$.

Laboratory analyses Antibody analyses were performed by MDS Pharma Services (Fehraltorf, Switzerland) using a RIA method [6]. The results are expressed as the percentage of bound radioactivity relative to the total. Because of intraassay variation, it is possible that samples with no or low levels of antibodies result in a negative value as a result of the subtraction of values from two assay series.

Insulin analysis was performed by Capio Diagnostik (Copenhagen, Denmark). Serum HI was measured by a commercially available two-site HI-specific ELISA (Dako, Glostrup, Denmark). Serum IAsp was measured by a twosite specific ELISA developed by Novo Nordisk. This assay is appropriate for measurements of IAsp at physiological concentrations $(0-1,000 \mathrm{pmol} / \mathrm{l})$ without crossreactivity with $\mathrm{HI}$. The total coefficient of variation for this assay is $14.7 \%$ [7] and the detection limit is $5.3 \mathrm{pmol} / \mathrm{l}$; levels below this value were set to zero. Insulin assays measured total insulin. A number of samples had to be discarded. This was mainly due to haemolysis, particularly of the insulin samples (40\%), and loss of sample stability as a result of late shipping ( $20 \%$ of the cord blood samples).

A total of 35 and 29 of the offspring whose mothers were treated with IAsp and HI, respectively, had valid cord blood insulin antibody measurements, whereas only 13 and 16 had valid cord blood insulin measurements. One participant treated with IAsp had cord blood measurements of $10,950 \mathrm{pmol} / 1$ for $\mathrm{HI}$ and $22.9 \mathrm{pmol} / 1$ for IAsp. As this unphysiologically high $\mathrm{HI}$ value suggested possible contamination, the result was considered invalid and all cord blood data for this participant were excluded from further analysis.

Statistics The development of maternal cross-reacting insulin antibodies, the relationship between cord blood and maternal cross-reacting insulin antibodies, and the relationship between birthweight and cord blood HI levels were analysed using linear regression. All values were logarithmically transformed. Treatment differences in cord blood HI levels were analysed using an ANOVA model with treatment as a fixed effect.

Table 2 Median levels of cord blood insulin antibody levels and cord blood insulin levels at delivery

\begin{tabular}{|c|c|c|c|c|c|c|c|}
\hline \multirow[t]{3}{*}{ Treatment } & \multirow[t]{3}{*}{ Antibody } & \multirow{2}{*}{\multicolumn{2}{|c|}{$\begin{array}{l}\text { Cord blood insulin } \\
\text { antibody levels }\end{array}$}} & \multicolumn{4}{|c|}{ Cord blood insulin levels at delivery } \\
\hline & & & & \multicolumn{2}{|c|}{ IAsp } & \multicolumn{2}{|l|}{ HI } \\
\hline & & $n$ & Median $(\%)$, range & $n$ & Median (pmol/l), range & $n$ & Median (pmol/l), range \\
\hline \multirow[t]{3}{*}{$\mathrm{IAsp}+\mathrm{NPH}$} & IAsp-specific & 35 & $0.1(-0.4-16.9)$ & \multirow[t]{3}{*}{13} & \multirow[t]{3}{*}{$0.0(0.0-0.0)$} & \multirow[t]{3}{*}{12} & \multirow[t]{3}{*}{$67.5(11.0-709)$} \\
\hline & HI-specific & 35 & $-0.02(-0.3-1.7)$ & & & & \\
\hline & Cross-reacting & 35 & $2.3(0.2-34.0)$ & & & & \\
\hline \multirow[t]{3}{*}{$\mathrm{HI}+\mathrm{NPH}$} & IAsp-specific & 29 & $0.2(-0.3-3.2)$ & \multirow[t]{3}{*}{16} & \multirow[t]{3}{*}{$0.0(0.0-0.0)$} & \multirow[t]{3}{*}{16} & \multirow[t]{3}{*}{$286.5(16.0-1,930)$} \\
\hline & HI-specific & 29 & $0.1(-0.3-3.8)$ & & & & \\
\hline & Cross-reacting & 29 & $4.4(-0.0-44.2)$ & & & & \\
\hline
\end{tabular}

NPH, neutral protamine Hagedorn 


\section{Results}

Levels of IAsp-specific antibodies and HI-specific antibodies were low at baseline and remained low during pregnancy, with similar levels observed between treatment groups at gestational week 36 (Table 1). A small but significant decrease in cross-reacting insulin antibodies was observed during pregnancy: the estimated regression coefficient of cross-reacting insulin antibodies at baseline (for the two groups together) was 0.8266 , which was significantly different from $1 \quad\left(p=0.0120, R^{2}=0.7612\right)$. There was no treatment effect $(p=0.9984)$. Duration of diabetes, pre-study use of IAsp or biphasic IAsp, and insulin dose were not correlated with level of cross-reacting antibodies at gestational week 36 in either treatment group (data not shown). There was a significant correlation between the level of cross-reacting insulin antibodies in cord blood and maternal cross-reacting insulin antibodies at gestational week 36 (regression coefficient $=0.9271, p<$ $\left.0.0001, R^{2}=0.9067\right)$, but no treatment effect $(p=0.9248)$. Two participants in the HI group had high levels of cord blood HI (1,150 and 1,930 pmol/l), but antibody levels were similar to the median levels observed in the cohort (Table 2). Sensitivity analyses excluding data from these two cord blood samples were performed for all analyses, with similar results. There was no correlation between birthweight and cord blood HI $(p=0.1590)$. IAsp was undetectable in the cord blood of all participants, including four individuals who received an i.v. infusion of IAsp during delivery (Table 2). There was no detection of IAsp in the umbilical cord blood of participants with high levels of insulin antibodies.

\section{Discussion}

Our results, which suggest that insulin antibodies do not develop during pregnancy when using either IAsp or HI, are reassuring and comparable to previous data involving non-pregnant participants with type 1 and type 2 diabetes [6] and those with gestational diabetes mellitus treated with IAsp or insulin lispro $[8,9]$. Overall, there was a small reduction in cross-reacting insulin antibodies in the IAsp group, perhaps similar to the decrease in levels seen with other types of antibody during pregnancy, such as serum antithyroglobulin [10]. The correlation between the level of maternal cross-reacting insulin antibodies and those in umbilical cord blood in the offspring is indicative of a transfer of maternal cross-reacting insulin antibodies across the placental barrier; however, there was no evidence to support the transfer of IAsp across the placenta.
This dataset on insulin antibodies in pregnancy is one of the largest reported to date and, we believe, provides new information on the use of insulin analogues in the management of type 1 diabetic pregnancy.

Trial registration: ClinicalTrials.gov NCT00365170

Acknowledgements This study was supported by Novo Nordisk. We would like to thank the investigators who participated in the study.

Duality of interest D. R. McCance, M. Hod, R. Kaaja and F. Dunne, have no dual interests to declare. P. Damm has received honoraria from Novo Nordisk. E. R. Mathiesen has received honoraria, grants and lecture fees from Novo Nordisk, and lecture fees from Aventis. L. E. Jensen is an employee of and shareholder in Novo Nordisk. H. Mersebach is an employee of Novo Nordisk.

\section{References}

1. Menon RK, Cohen RM, Sperling MA, Cutfield WS, Mimouni F, Khoury JC (1990) Transplacental passage of insulin in pregnant women with insulin-dependent diabetes mellitus. Its role in fetal macrosomia. N Engl J Med 323:309-315

2. Weiss PA, Kainer F, Haas J (1998) Cord blood insulin to assess the quality of treatment in diabetic pregnancies. Early Hum Dev 51:187-195

3. Lindsay RS, Ziegler AG, Hamilton BA, Calder AA, Johnstone FD, Walker JD, Scottish Multicentre Study of Diabetes in Pregnancy (2004) Type 1 diabetes-related antibodies in the fetal circulation: prevalence and influence on cord insulin and birth weight in offspring of mothers with type 1 diabetes. J Clin Endocrinol Metab 89:3436-3439

4. Mathiesen E, Kinsley B, McCance D et al (2007) Maternal hypoglycemia and glycemic control in pregnancy: a randomized trial comparing insulin aspart with human insulin in 322 subjects with type 1 diabetes. Diabetes Care 30:771-776

5. Hod M, Damme P, Kaaja R, the Insulin Aspart Pregnancy Study Group et al (2008) Fetal and perinatal outcomes in type 1 diabetes pregnancy: a randomized study comparing insulin aspart with human insulin in 322 subjects. Am J Obstet Gynecol 198:186.e1-186.e7

6. Lindholm A, Jensen L, Home P, Raskin P, Boehm BO, Råstam J (2002) Immune responses to insulin aspart and biphasic insulin aspart in people with type 1 and type 2 diabetes. Diabetes Care 25:876-882

7. Andersen L, Jorgensen PN, Jensen LB, Walsh D (2000) A new insulin immunoassay specific for the rapid-acting insulin analog, insulin aspart, suitable for bioavailability, bioequivalence, and pharmacokinetic studies. Clin Biochem 33:627-633

8. Jovanovic L, Ilic S, Pettitt DJ et al (1999) Metabolic and immunologic effects of insulin lispro in gestational diabetes. Diabetes Care 22:1422-1427

9. Pettitt D, Ospina P, Howard C Zisser H, Jovanovic L (2007) Efficacy, safety and lack of immunogenicity of insulin aspart versus regular human insulin for women with gestational diabetes mellitus. Diabet Med 24:1129-1135

10. D’Armiento M, Salabé H, Vetrano G, Scucchia M, Pachi A (1980) Decrease of thyroid antibodies during pregnancy. J Endocrinol Invest 3:437-438 